\title{
Human immunodeficiency virus infection predictors and genetic diversity of hepatitis $B$ virus and hepatitis $C$ virus co-infections among drug users in three major Kenyan cities
}

\begin{tabular}{|c|c|}
\hline $\begin{array}{l}\text { Authors: } \\
\text { Micah Oyaro }{ }^{1} \\
\text { John Wylie } \\
\text { Chien-Yu Cher } \\
\text { Raphael O. Or } \\
\text { Anna Kramvis }\end{array}$ & (D) \\
\hline $\begin{array}{l}\text { Affiliations: } \\
{ }^{1} \text { Immunology } \\
\text { Department } \\
\text { Pathology, Un } \\
\text { Nairobi, Keny }\end{array}$ & $\begin{array}{l}\text { Unit, } \\
\text { f Human } \\
\text { iversity of }\end{array}$ \\
\hline $\begin{array}{l}{ }^{2} \text { Department } \\
\text { Microbiology, } \\
\text { Manitoba, Ca }\end{array}$ & $\begin{array}{l}\text { f Medical } \\
\text { University of } \\
\text { lada }\end{array}$ \\
\hline $\begin{array}{l}{ }^{3} \text { Hepatitis Vir } \\
\text { Research Unit } \\
\text { Department } \\
\text { Medicine, Sch } \\
\text { Medicine, Fac } \\
\text { Sciences, Univ } \\
\text { Witwatersran }\end{array}$ & $\begin{array}{l}\text { s Diversity } \\
\text { (HVDRU), } \\
\text { f Internal } \\
\text { ool of Clinical } \\
\text { ulty of Health } \\
\text { ersity of the } \\
\text { d, South Africa }\end{array}$ \\
\hline $\begin{array}{l}{ }^{4} \text { Department } \\
\text { Laboratory Sc } \\
\text { Muliro Univer } \\
\text { and Technolo }\end{array}$ & $\begin{array}{l}\text { f Medical } \\
\text { ences, Masinde } \\
\text { sity of Science } \\
\text { y, Kenya }\end{array}$ \\
\hline $\begin{array}{l}{ }^{5} \text { Kenya Medic } \\
\text { Institute, Cen } \\
\text { Microbiology } \\
\text { Nairobi, Keny }\end{array}$ & $\begin{array}{l}\text { Research } \\
\text { re for } \\
\text { Research, }\end{array}$ \\
\hline $\begin{array}{l}\text { Correspondin } \\
\text { Anna Kramvis } \\
\text { anna.kramvis }\end{array}$ & $\begin{array}{l}\text { g author: } \\
\text { @wits.ac.za }\end{array}$ \\
\hline $\begin{array}{l}\text { Dates: } \\
\text { Received: } 03 \text { F } \\
\text { Accepted: } 02 \\
\text { Published: } 27\end{array}$ & $\begin{array}{l}\text { eb. } 2017 \\
\text { Oct. } 2017 \\
\text { Mar. } 2018\end{array}$ \\
\hline Read online: & \\
\hline 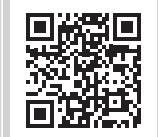 & $\begin{array}{l}\text { Scan this QR } \\
\text { code with your } \\
\text { smart phone or } \\
\text { mobile device } \\
\text { to read online. }\end{array}$ \\
\hline
\end{tabular}

Background: Drug users act as reservoirs and transmission channels for hepatitis B virus (HBV), hepatitis C virus (HCV) and human immunodeficiency virus (HIV) infections to the general population worldwide. Periodic epidemiological studies to monitor the prevalence and genetic diversity of these infections to inform on interventions are limited.

Objective of the study: The objective of this study was to determine the predictors of HIV infection and genetic diversity of HBV and HCV among drug users in Kenya.

Materials and methods: A cross-sectional study on previous drug use history among drug users was conducted in three Kenyan cities using a respondent-driven sampling method between January 2011 and September 2012. Blood samples were collected and analysed for the presence of $\mathrm{HBV}, \mathrm{HCV}$ and HIV serological markers and to determine the genotypes of $\mathrm{HBV}$ and HCV.

Results: The overall prevalence of HBV, HCV and HIV among drug users was $4.3 \%, 6.5 \%$ and $11.1 \%$, respectively, with evidence of $\mathrm{HBV} / \mathrm{HIV}, \mathrm{HCV} / \mathrm{HIV}$ and $\mathrm{HBV} / \mathrm{HCV} / \mathrm{HIV}$ co-infections. The HBV circulating genotypes were A1 (69\%) and D6 (19\%), whereas HCV genotypes were 1a (72\%) and $4 \mathrm{a}(22 \%)$. Injection drug use was a significant predictor of $\mathrm{HIV} / \mathrm{HCV}$ infections. Younger age (30 years; aOR (adjusted odds ratio) $=0.50,95 \%$ CI (confidence interval): $0.33-0.76 ; p<0.001)$ and early sexual debut $(\mathrm{aOR}=0.54,95 \% \mathrm{CI}: 0.40-0.82 ; p<0.05)$ were negatively associated with detection of any of the three infections. Injecting drug use was positively associated with $\mathrm{HCV}$ infection $(\mathrm{aOR}=5.37,95 \% \mathrm{CI}: 2.61-11.06 ; p<0.001)$.

Conclusion: This high level of genetic diversity exhibited by HBV and HCV isolates requires urgent implementation of harm reduction strategies and continuous monitoring for effective management of the patients.

\section{Introduction}

Substance abuse is a growing phenomenon and infection with blood-borne pathogens among drug users is a great problem around the world. Human immunodeficiency virus (HIV), hepatitis B virus (HBV) and hepatitis $\mathrm{C}$ virus (HCV) are common infections among drug users both injecting drug users (IDUs) and non-injecting drug users (NIDUs). ${ }^{1,2}$ Being blood-borne, $\mathrm{HBV}, \mathrm{HCV}$ and $\mathrm{HIV}$ infections are commonly transmitted through unsafe drug injection practices and sexual contact. ${ }^{3}$ Both HBV and HCV have been implicated in acute and chronic liver disease, with a rapid progression to liver cirrhosis and hepatocellular carcinoma. ${ }^{4,5}$ Currently, over 2 billion people worldwide are infected with HBV and about 240 million are chronic carriers. ${ }^{6}$ Approximately 780000 deaths occur annually as a result of HBV infection, with an estimated 4.5 million new HBV infections occurring each year. ${ }^{7}$ An estimated 170 million people are infected with HCV worldwide with more than 350000 deaths annually. ${ }^{8}$ Approximately, 26 million of the 37 million HIV-positive individuals in the world reside in Sub-Saharan Africa, ${ }^{9}$ highlighting the disproportionate impact this pathogen is having on this region of the world, which includes Kenya. Within the East African countries, Uganda has an HIV prevalence of 7.3\% with 1.6 million people living with HIV. ${ }^{10}$ Tanzania has an HIV prevalence of $4.7 \%$ with an estimated 1.4 million people living with HIV ${ }^{11}$ while in Kenya, an HIV prevalence of $5.9 \%$ with

How to cite this article: Oyaro M, Wylie J, Chen C-Y, Ondondo RO, Kramvis A. Human immunodeficiency virus infection predictors and genetic diversity of hepatitis B virus and hepatitis $C$ virus co-infections among drug users in three major Kenyan cities. S Afr J HIV Med. 2018;19(1), a737. http://doi.org/10.4102/sajhivmed.v19i1.737

Copyright: @ 2018. The Authors. Licensee: AOSIS. This work is licensed under the Creative Commons Attribution License. 
an estimated 1.5 million people living with HIV has been documented. ${ }^{11}$ Previous data have shown HBV prevalence of $10 \%, 13.3 \%$ and $8.8 \%$ in Uganda, Kenya and Tanzania, respectively. ${ }^{12,13,14}$ Studies on HCV prevalence from Kenya, Uganda and Tanzania have shown a prevalence of $1.8 \%$, $2.6 \%$ and $1.2 \%$, respectively. $15,16,17$

Drug abuse in Kenya drew national interest in the early 1990s, with the emergence of the Kenyan HIV epidemic, and the phenomenon continues to increase faster in Kenya, as well as among other East African countries. ${ }^{18}$ Although substance abuse is widespread across major towns in Kenya, ${ }^{19}$ the practice is more common in the cosmopolitan coastal regions as a result of tourism, illicit drug trafficking and cultural practices. ${ }^{20,21}$

The majority of people who inject drugs in Kenya are concentrated in Nairobi and Mombasa ${ }^{22}$, although evidence of IDU has also been documented from Kisumu. ${ }^{23}$ The same practice has been reported from other East African major cities, which include Mwanza ${ }^{24}$ and Dar es Salaam in Tanzania, ${ }^{25}$ Zanzibar $^{26}$ and Mauritius. ${ }^{27}$

Although HBV, HCV and HIV viral infections are considered to be endemic in Africa, the prevalence of HCV/HIV and $\mathrm{HBV} / \mathrm{HIV}$ co-infections, as well as mono-infections, varies depending on the risk factors, individual behaviours, sociodemographic profiles and HBV immunisation coverage. A study conducted in two informal urban settlements in Nairobi, Kenya, showed HBV, HCV and HIV prevalence of $13.3 \%, 0.76 \%$ and $20.4 \%$, respectively. ${ }^{14}$ Anti-HCV prevalence among blood donors in Nairobi was $1.8 \%,{ }^{15}$ whereas among outpatients from three hospitals, an HBV surface antigen (HBsAg) positivity of $11.4 \%$ was documented. ${ }^{28}$ An HIV prevalence of $18.7 \%$ was reported among IDUs in Nairobi ${ }^{7}$ and $87.5 \%$ among injecting heroin users at the Kenyan coast, ${ }^{29}$ whereas an $\mathrm{HCV}$ prevalence of $16.4 \%$ and $\mathrm{HCV} / \mathrm{HIV}$ coinfection prevalence of $17.9 \%$ among the same heroin users was documented. ${ }^{29}$

Hepatitis B virus belongs to the family Hepadnaviridae with a genome sequence of 3200 nucleotides in length. ${ }^{30}$ The partially double-stranded DNA has four overlapping open reading frames encoding the $S$ (surface), $C$ (core), $\mathrm{P}$ (polymerase) and $\mathrm{X}$ genes. The virus has a high mutation rate because the reverse transcriptase lacks proofreading ability with an estimated nucleotide substitution rate of $10^{-3}-10^{-6} /$ site per year. ${ }^{31}$ This error-prone replication accounts for point mutations, insertions and deletions found in HBV genotypes/subgenotypes. ${ }^{32} \mathrm{HBV}$ is classified into nine genotypes (A-I) and a putative genotype, ' $\mathrm{J}$ '. ${ }^{33}$ Depending on intergroup nucleotide divergence, HBV genotypes have been further classified into at least 35 subgenotypes. ${ }^{34,35}$ The global distribution of HBV genotypes and subgenotypes has been reviewed and shows distinct distribution, diversity and ability to adapt to different hosts. ${ }^{35}$ Within the African continent, HBV genotype A is confined to eastern, central and southern Africa, whereas genotype D prevails in northern countries and genotype $\mathrm{E}$ in western and central Africa. In Kenya, subgenotypes A1, D6 and D/E recombinant have been identified. ${ }^{36,37,38}$

Similarly, HCV exhibits a high degree of genetic diversity, which can create challenges in immune control and therapeutic intervention. ${ }^{39} \mathrm{HCV}$ strains have been classified into seven genotypes and 67 subgenotypes. ${ }^{40} \mathrm{HCV}$ genotypes differ at $30 \%-35 \%$ of nucleotide sites whereas subtypes, strains of the same genotype, differ at $<15 \%$ nucleotide sites (43). Subtypes $1 \mathrm{a}, 1 \mathrm{~b}, 2 \mathrm{a}$ and $3 \mathrm{a}$ have a global distribution. ${ }^{41,42,43}$ Genotypes 1, 2, 4 and 5 have endemic origins in Africa, with genotypes 1 and 2 occurring throughout Africa, genotype 4 in Egypt and parts of Central Africa and genotype 5 in southern Africa, and less commonly in some parts of central Africa. ${ }^{4}$

Two studies have been conducted to determine the prevalence, genetic diversity and distribution of HBV and $\mathrm{HCV}$ among drug users in Kenya. One of these studies found A1 as the dominant HBV genotype circulating among HIVinfected and HIV-uninfected drug users in coastal Kenya ${ }^{45}$ while the laboratory-based study among drug users from Nairobi found HCV genotypes $1 \mathrm{a}(73 \%)$ and $4(27 \%) .{ }^{46}$ More information on the epidemiology and genetic distribution of $\mathrm{HBV}$ and HCV genotypes among drug users from major towns in Kenya to inform on appropriate interventions is needed. The objective was to determine the prevalence and genetic distribution of these viruses among drug users in Nairobi, Mombasa and Kisumu, towns in Kenya.

\section{Materials and methods Study population and data collection}

A cross-sectional study among drug users (both injectors and non-injectors) on their previous drug use history using respondent-driven sampling (RDS) was conducted between January 2011 and September 2012. Through community seminars and RDS techniques, drug users from communities in Nairobi, Mombasa and Kisumu, cities in Kenya, were recruited. A group of trained nurse counsellors, community mobilisers and former drug addicts, with prior working experience on drug abuse cohorts, were employed to facilitate recruitment of participants. Male and female participants, aged 18 years or older, self-reported drug users and/or who had engaged in sex-related or drug-related HIV risk behaviours at least once monthly for three months prior to recruitment and willing to provide blood were eligible for recruitment into the study. The venues for recruitment were agreed upon by the group leader or representative. The initial potential participants from each city chosen by recruiters were referred to as 'seeds' and were provided with a coupon that they used to invite other members from their networks, whom they considered as potential participants for the study. Interviewers obtained signed informed consent from participants. All participants were able to read and understand the questionnaire in English without any translation. Participants who gave their consent were administered a quantitative questionnaire, counselled and blood specimens obtained. 
The questionnaire captured data on social demographic characteristics, risk factors and previous history on substance-use behaviours. Pre-and post-test counselling for $\mathrm{HIV}$ and other blood-borne infections (HBV/HCV) were offered as a package in the study. Participants were reimbursed with KSH 350 (US\$ 7) for their time. The study was reviewed and approved by both Kenyatta National Hospital Ethics Research Committee (KNH/UON-ERC), approval \# P144/5/2010, and University of Manitoba Health Research Ethics Board (HREB), approval \# HS10896 (H2010:100), before it was conducted. The molecular testing of de-identified blood specimens for HBV and HCV was also approved by the Human Ethics Committee of the University of the Witwatersrand.

A total of $20 \mathrm{~mL}$ of venous blood $(10 \mathrm{~mL}$ in EDTA tubes and $10 \mathrm{~mL}$ in plain tubes) was obtained from eligible individuals. Blood specimens were centrifuged and separated into plasma and serum, respectively, before being aliquoted into two parts and stored frozen at $-80^{\circ} \mathrm{C}$ until analysed to determine prevalence of $\mathrm{HIV}, \mathrm{HBV}$ and $\mathrm{HCV}$, and identification of hepatitis $B$ and $C$ viral genotypes. Participants who tested positive for HIV, HBV and HCV were referred to clinical centres for treatment and further follow-up.

All participants were well informed about the study and their participation was kept confidential through a written consent and unique identifiers given to their samples, questionnaires and laboratory request forms including personal data. Descriptive statistics were presented as proportions and prevalence presented as \% point estimate with its $95 \%$ confidence interval (CI). Differences in categorical variables were tested using Chi square and odds ratio (OR) for binary variables reported at 95\% significance level $(p<0.05)$ using Stata version 14 (StataCorp 4905 Lakeway Drive, College Station, Texas 77845 USA)

\section{Laboratory testing procedures}

\section{Human immunodeficiency virus, hepatitis B virus and hepatitis $\mathbf{C}$ virus serology}

Specimens were screened for HBV, HCV and HIV infection using HepanostikaHBsAgUltra ${ }^{\mathrm{TM}}$ enzyme-linked immunosorbent assay (ELISA) (Biomerieux, France), AxSYM $\mathrm{HCV}$ (Abbott, Mississauga, ON) and AxSYM HIV1/2 gO (Abbott, Mississagua, $\mathrm{ON}$ ), respectively.

\section{Hepatitis B virus viral DNA isolation, amplification and sequencing}

Hepatitis B virus DNA extraction: Hepatitis B virus DNA was extracted from the plasma samples using the QIAampDNABlood Mini Kit (QIAGEN GmbH, Hilden, Germany) according to the manufacturer's instructions, and eluted in $100 \mu \mathrm{L}$ of elution buffer. Known positive, negative sera and best-quality water were included as controls for the extraction.

Hepatitis B virus amplification: The basic core promoter/ precore $(\mathrm{BCP} / \mathrm{PreC})$ region and complete $\mathrm{S}$ open read frame were individually amplified from the extracted specimen using nested polymerase chain reaction (PCR) primer sets. ${ }^{47}$ PCR reactions were carried out in the $\mathrm{MyCycler}^{\mathrm{TM}}$ thermocycler (Bio-Rad, Hercules, CA, USA). BCP/PreC PCR amplified from the nt 1606 to nt 1974 (from EcoRI site) by using BCP1 and BCP2 primer sets with PromegaTaq DNA polymerase (Promega, Madison, WI, USA). The complete $S$ open reading frame (nt 2451 to 1254 from EcoRI site) was amplified using S1F/S1R and S2F/S2R primer sets together with HotStarTaq Master Mix (QIAGEN GmbH, Hilden, Germany).

Hepatitis B virus serology-negative specimens that did not amplify in the complete $S$ region were subjected to the nested PCR to amplify the target surface region (nt 256 to nt 796 from EcoRI site). The amplicons were amplified using primer set 230F/800R for the first-round PCR, ${ }^{48}$ and primer set P7/ P8 for second-round $\mathrm{PCR}^{49}$ together with PromegaTaq DNA polymerase (Promega, Madison, WI, USA). Amplicons were genotyped by restriction fragment length polymorphism (RFLP) analysis using HinfI and Tsp509I. ${ }^{49}$

Hepatitis B virus sequencing: Amplicons were prepared for direct sequencing using HBV-specific primers and the BigDye Terminator v3.0 Cycle Sequencing Ready Reaction Kit (Applied Biosystems., Foster City, CA, USA). Sequencing was performed by the Central Analytical Facility, Stellenbosch University, South Africa, using the ABI 3130XL Genetic analyser (Applied Biosystems, Foster City, CA, USA). BCP/ PreC sequences were analysed in the forward direction of a single fragment, while the complete $\mathrm{S}$ sequences of three overlapping fragments were analysed. The genotype or subgenotype could not be assigned in samples that failed to amplify in both the BCP and S region whereas those that amplified in either or both regions could be genotyped or subgenotyped

Hepatitis B virus viral load quantification: Hepatitis B virus viral load was quantified by real-time quantitative PCR using HBV-Taq1 and HBV-Taq2 primer sets together with the FAM/TAMRA labelled TaqMan BS-1 probe as previously described. ${ }^{50,51}$ The PCR reaction was performed using the ABI Prism 7500 (Applied Biosystems, Framingham, MA, USA).

Serial dilutions of the plasmid encoding a single genome of HBV DNA ranging from $10^{2} \mathrm{IU} / \mathrm{mL}$ to $10^{9} \mathrm{IU} / \mathrm{mL}$ were used to generate a linear standard curve. The second World Health Organization (WHO) International Standard for HBV Nucleic Acid Amplification Techniques, product code $97 / 750$, with the final concentration of $1 \mathrm{IU} / \mathrm{mL} \times 10^{6} \mathrm{IU} / \mathrm{mL}$, was obtained from the National Institute for Biological Standards and Controls (NIBSC; Hertfordshire, UK). It was used as an internal positive control to calibrate and align the standard curve. The standard curve, blank, positive and negative controls and samples were all tested in duplicate. 


\section{Hepatitis C virus viral ribonucleic acid isolation, amplification and sequencing}

\section{Hepatitis C virus RNA extraction and CDNA synthesis}

Hepatitis C virus RNA was extracted from 38 out of 42 (90\%) HCV serology-positive specimens, using the QiaAmp RNA mini kit (QIAGEN GmbH, Hilden, Germany), according to the manufacturer's instructions. Known positive and negative sera and best-quality water were used as controls for the extraction procedure. HCV RNA was eluted with $60 \mu \mathrm{L}$ elution buffer provided by the kit with the addition of RNase inhibitor (at final concentration of $1 \mathrm{U} / \mu \mathrm{L}$ ). Firststrand HCV cDNA was synthesised immediately after extraction using the Superscript III First-strand synthesis system for RT-PCR (Invitrogen, Carlsbad, CA, USA) using the random hexamer at $100 \mathrm{ng}$ per reaction.

\section{Hepatitis $C$ virus amplification}

5 'untranslated region (5'UTR), for HCV genotyping, and NS5B region, for HCV sub-typing, were amplified individually from the cDNA using nested PCR. Known HCV negative, positive sera best-quality water together with full length HCV Strain H77 (genotype 1a), pCNJ4C6S (HCV genotype $1 b$ ) and pJ6CF2a (HCV genotype 2a) HCV plasmid clones (obtained from Prof R. Purcell, NIH, USA) were included as controls.

5'untranslated region was amplified using published primers. ${ }^{52}$ Nested PCRs were carried out using Hotstar master mix (QIAGEN GmbH, Hilden, Germany) using $4 \mu \mathrm{L}$ cDNA as template with forward and reverse primers at $1 \mu \mathrm{M}$ final concentration in a final volume of $25 \mu \mathrm{L}$ PCR mix. The cycling conditions were: an initial activation at $95^{\circ} \mathrm{C}$ for $15 \mathrm{~min}$, followed by 40 cycles of denaturation at $94^{\circ} \mathrm{C}$ for $1 \mathrm{~min}$, annealing at $50^{\circ} \mathrm{C}$ for $1 \mathrm{~min}$, extension at $72^{\circ} \mathrm{C}$ for $1.5 \mathrm{~min}$, followed by final extension at $72^{\circ} \mathrm{C}$ for $10 \mathrm{~min}$. The second-round PCR used the same cycling condition as the first-round PCR.

NS5B region was amplified using published primers. ${ }^{53}$ Nested PCRs were carried out using Hotstar master mix (QIAGEN GmbH, Hilden, Germany) using $4 \mu \mathrm{L}$ cDNA as template with forward and reverse primers at $1 \mu \mathrm{M}$ final concentration in a final volume of $25 \mu \mathrm{L}$ PCR mix. The cycling profile for the NS5B region was: an initial activation at $95^{\circ} \mathrm{C}$ for $15 \mathrm{~min}$, followed by 40 cycles of denaturation at $94^{\circ} \mathrm{C}$ for $1 \mathrm{~min}$, annealing at $60^{\circ} \mathrm{C}$ for $1 \mathrm{~min}$, extension at $72^{\circ} \mathrm{C}$ for $1 \mathrm{~min}$, followed by final extension at $72^{\circ} \mathrm{C}$ for $5 \mathrm{~min}$. The second-round PCR used the same cycling conditions as the first-round PCR.

\section{Hepatitis $\mathrm{C}$ virus sequencing}

The amplicons were prepared for direct sequencing using the BigDye Terminator v3.0 Cycle Sequencing Ready Reaction Kit (Applied Biosystems., Foster City, USA) using secondround forward PCR primers. Sequencing was performed by the Central Analytical Facility, Stellenbosch University, South Africa, using the ABI 3130XL Genetic analyser (Applied
Biosystems, Foster City, CA). 5'UTR and NS5B region sequences were analysed in the forward directions of a single fragment.

\section{Ethical consideration}

The study was reviewed and approved by both Kenyatta National Hospital University of Nairobi Ethics and Research Committee (KNH/UON-ERC) (approval \# P144/5/2010) and University of Manitoba Health Research Ethics Board (HREB) (approval \# HS10896) (H2010:100), before it was conducted. The molecular testing of de-identified blood specimens for HBV and HCV was also approved by the Human Ethics Committee of the University of the Witwatersrand.

\section{Results}

Out of the 673 drug users enrolled, 626 (93\%) were males, $74 \%$ (501/673) were NIDUs, while the remaining 26\% were IDUs. Majority of the participants were aged between 20 and 34 years. Almost half of the participants, 304 (49.8\%), had their main source of income from regular work, 158 (25.9\%) from friends, and 128 (21\%) from self-employment. None of the major tribes in Kenya (Kikuyu, Luyia and Luo) had a majority representation, indicating a mixed society when all participants were analysed together. Almost equal proportion of participants either stayed in rented houses (250 [40.1\%]) or in a family member's house (279 [44.7\%]).

Overall, the prevalence was $11.1 \%$ (95\% CI: 8.7 - 13.5) for HIV, $4.3 \%$ (95\% CI: 2.8 - 5.8) for HBV and 6.5\% (95\% CI: $4.64-$ 8.4) for HCV. The prevalence of HIV, HBV and HCV in men was 10.5\% (95\% CI: 8.1 - 12.9), 4.5\% (95\% CI: 2.9 - 6.1) and $6.6 \%$ (95\% CI: $4.7-8.6)$, respectively, whereas for women it was $19.1 \%$ (95\% CI: $7.9-30.3), 2.1 \%$ (95\% CI: $0.38-11.12)$ and $6.4 \%$ (95\% CI: $2.19-17.16)$, respectively (Table 1). Among the 23 samples with HBV mono-infections, 12 samples (52\%) were from Nairobi, seven samples (30\%) from Mombasa and four samples (17\%) from Kisumu. Similarly, 27 samples had HCV mono-infections; out of these, 25 samples (93\%) were from Mombasa, whereas two samples $(7 \%)$ were from Nairobi. None of the samples collected from Kisumu participants tested positive for HCV mono-infection.

Mono-infections were detected in 99 drug users, of whom $16(16.2 \%)$ were IDUs, $72(72.7 \%)$ were NIDUs and $11(11.1 \%)$ were unclassified drug users. IDU was significantly associated with mono-infection among those detected with any of the three infections (OR $=4.5$ [95\% CI: 1.66-12.54], $p<0.01)$. Young age (30 years old) was not associated with mono-infection $(\mathrm{OR}=1.91$ [95\% CI: 0.73-5-04], $p=0.22)$. Dual infections were detected in 22 drug users (10-IDUs, 8-NIDUs and 4-unclassified). Regarding HIV and hepatitis co-infections, $\mathrm{HIV} / \mathrm{HCV}$ co-infections were observed in 18 participants; $13(72 \%)$ were IDUs and five (28\%) were NIDUs. HIV / HBV co-infections were reported among six participants - one sample (17\%) from IDUs and five (83\%) from NIDUs. Triple co-infections ( $\mathrm{HBV} / \mathrm{HCV} / \mathrm{HIV})$ were detected in two patients (one from an IDU and another from NIDU). 
TABLE 1: Participant demographics and disease prevalence among drug users in three major cities in Kenya.

\begin{tabular}{|c|c|c|c|c|c|c|c|c|c|c|c|}
\hline \multirow{2}{*}{$\begin{array}{l}\text { Participant } \\
\text { characteristics }\end{array}$} & \multirow[t]{2}{*}{ Variable } & \multicolumn{3}{|c|}{ Male $(n=626)$} & \multicolumn{3}{|c|}{ Female $(n=47)$} & \multicolumn{3}{|c|}{ Total $(n=673)$} & \multirow[t]{2}{*}{$p$} \\
\hline & & $n$ & $\%$ & $95 \% \mathrm{Cl}$ & $n$ & $\%$ & $95 \% \mathrm{Cl}$ & $n$ & $\%$ & $95 \% \mathrm{Cl}$ & \\
\hline \multirow[t]{5}{*}{ Age (years) } & $15-19$ & 31 & 5.0 & - & 6 & 12.8 & - & 37 & 5.5 & - & 0.037 \\
\hline & $20-24$ & 223 & 35.6 & - & 18 & 38.3 & - & 241 & 35.8 & - & 0.712 \\
\hline & $25-29$ & 144 & 23.0 & - & 6 & 12.8 & - & 150 & 22.3 & - & 0.104 \\
\hline & $30-34$ & 130 & 20.8 & - & 6 & 12.8 & - & 136 & 20.2 & - & 0.188 \\
\hline & $>34$ & 98 & 15.7 & - & 11 & 23.4 & - & 109 & 16.2 & - & 0.164 \\
\hline \multirow{2}{*}{ Education level } & Secondary school level & 187 & 30.2 & - & 17 & 36.2 & - & 204 & 30.6 & - & 0.365 \\
\hline & Tertiary level & 40 & 6.4 & - & 1 & 2.1 & - & 41 & 6.1 & - & 0.239 \\
\hline \multirow{4}{*}{$\begin{array}{l}\text { Main source of } \\
\text { income }\end{array}$} & Regular employment & 304 & 49.8 & - & 24 & 52.2 & - & 328 & 50.0 & - & 0.013 \\
\hline & Friends and relatives & 158 & 25.9 & - & 8 & 17.4 & - & 166 & 25.3 & - & 0.208 \\
\hline & Self employed & 128 & 21.0 & - & 12 & 26.1 & - & 140 & 21.3 & - & 0.408 \\
\hline & Other & 20 & 3.3 & - & 2 & 4.3 & - & 22 & 3.4 & - & 0.694 \\
\hline \multirow[t]{4}{*}{ Ethnic group } & Luo & 115 & 19.4 & - & 7 & 14.9 & - & 122 & 19.1 & - & 0.036 \\
\hline & Kikuyu & 43 & 7.3 & - & 7 & 14.9 & - & 50 & 7.8 & - & 0.043 \\
\hline & Kamba & 33 & 5.6 & - & 5 & 10.6 & - & 38 & 5.9 & - & 0.124 \\
\hline & Other & 339 & 54.2 & - & 23 & 49.0 & - & 362 & 53.8 & - & 0.489 \\
\hline \multirow{4}{*}{$\begin{array}{l}\text { Place lived most in the } \\
\text { last } 6 \text { months }\end{array}$} & Own house & 250 & 40.1 & - & 16 & 34.0 & - & 266 & 39.6 & - & 0.426 \\
\hline & Family member's house & 279 & 44.7 & - & 22 & 46.8 & - & 301 & 44.9 & - & 0.766 \\
\hline & Friend's house & 63 & 10.1 & - & 7 & 14.9 & - & 70 & 10.4 & - & 0.296 \\
\hline & Other & 32 & 5.1 & - & 2 & 4.3 & - & 34 & 5.1 & - & 0.796 \\
\hline \multirow{3}{*}{$\begin{array}{l}\text { Infection } \\
\text { Prevalence }\end{array}$} & $\operatorname{HIV}(n=673)$ & 66 & 10.5 & $8.1,12.9$ & 9 & 19.1 & $7.86,30.34$ & 75 & 11.1 & $8.73,13.47$ & - \\
\hline & $\mathrm{HBV}(n=673)$ & 28 & 4.5 & $2.88,6.12$ & 1 & 2.1 & $0.38,11.12$ & 29 & 4.3 & $2.77,5.83$ & - \\
\hline & $\mathrm{HCV}(n=672)$ & 41 & 6.6 & $4.65,8.55$ & 3 & 6.4 & $2.19,17.16$ & 44 & 6.5 & $4.64,8.36$ & - \\
\hline
\end{tabular}

$\mathrm{Cl}$, confidence interval; HIV, human immunodeficiency virus; $\mathrm{HCV}$, hepatitis $\mathrm{C}$ virus; $\mathrm{HBV}$, hepatitis $\mathrm{B}$ virus.

TABLE 2: Predictors of human immunodeficiency virus infection among drug users from three major cities in Kenya.

\begin{tabular}{|c|c|c|c|c|c|c|}
\hline Characteristic & Category & $N$ & $n$ & $\%$ & $\begin{array}{c}\text { Chi square } \\
\left(\chi^{2}\right)\end{array}$ & $p$ \\
\hline \multirow[t]{6}{*}{ Age (years) } & $15-19$ & 37 & 4 & 10.8 & 10.388 & 0.065 \\
\hline & $20-24$ & 241 & 18 & 7.5 & & \\
\hline & $25-29$ & 150 & 15 & 10.0 & & \\
\hline & $30-34$ & 136 & 24 & 17.6 & & \\
\hline & $35-39$ & 80 & 9 & 11.3 & & \\
\hline & $\geq 40$ & 29 & 5 & 17.2 & & \\
\hline \multirow[t]{2}{*}{ Sex } & Male & 626 & 66 & 10.5 & 3.270 & 0.071 \\
\hline & Female & 47 & 9 & 19.1 & & \\
\hline \multirow[t]{2}{*}{ HBV infection } & Positive & 29 & 7 & 24.1 & 5.167 & 0.023 \\
\hline & Negative & 644 & 68 & 10.6 & & \\
\hline \multirow[t]{2}{*}{ HCV infection } & Positive & 44 & 18 & 40.9 & 42.947 & 0.000 \\
\hline & Negative & 628 & 56 & 8.9 & & \\
\hline \multirow{3}{*}{$\begin{array}{l}\text { Current town } \\
\text { of residence }\end{array}$} & Kisumu & $\mathrm{N}-121$ & 22 & 18.2 & 14.364 & 0.001 \\
\hline & Mombasa & 305 & 39 & 12.8 & & \\
\hline & Nairobi & 247 & 14 & 5.7 & & \\
\hline \multirow{2}{*}{$\begin{array}{l}\text { Level of } \\
\text { education }\end{array}$} & $\geq$ Grade 12 & 228 & 30 & 13.2 & 0.336 & 0.562 \\
\hline & $<$ Grade 12 & 296 & 34 & 11.5 & & \\
\hline \multirow{4}{*}{$\begin{array}{l}\text { Main source } \\
\text { of income }\end{array}$} & Regular work & 328 & 48 & 14.6 & 8.573 & 0.036 \\
\hline & Welfare & 140 & 8 & 5.7 & & \\
\hline & From friends & 166 & 16 & 9.6 & & \\
\hline & Other & 22 & 2 & 9.1 & & \\
\hline \multirow[t]{4}{*}{ Ethnicity } & Kikuyu/Kamba & 88 & 6 & 6.8 & 9.552 & 0.023 \\
\hline & Luo & 122 & 21 & 17.2 & & \\
\hline & Luyia & 68 & 3 & 4.4 & & \\
\hline & Other & 362 & 39 & 10.8 & & \\
\hline \multirow{2}{*}{$\begin{array}{l}\text { Injected } \\
\text { non-prescribed } \\
\text { drug }\end{array}$} & Yes & 120 & 19 & 15.8 & 3.392 & 0.007 \\
\hline & No & 501 & 48 & 9.6 & & \\
\hline \multirow{3}{*}{$\begin{array}{l}\text { Age at sexual } \\
\text { debut }\end{array}$} & $<15$ & 127 & 11 & 8.7 & 2.986 & 0.225 \\
\hline & $15-19$ & 344 & 45 & 13.1 & & \\
\hline & $\geq 20$ & 179 & 16 & 8.9 & & \\
\hline
\end{tabular}

$\mathrm{HBV}$, hepatitis B virus; $\mathrm{HCV}$, hepatitis C virus.
Majority of HBV / HIV co-infected were from Kisumu, that is, five samples $(83 \%)$, and only one sample $(17 \%)$ was from Mombasa. All HCV / HIV co-infections (100\%) were detected among participants recruited from Mombasa town and majority (> 70\%) were IDUs.

Among drug users studied, $\mathrm{HBV}$ and $\mathrm{HCV}$ infections were significant $(p<0.05)$ predictors of HIV infection (Table 2$)$, partially explained by the three viruses sharing modes of transmission. The towns from which drug users were recruited and their ethnicity significantly predicted HIV infection, suggesting geographical differences in ethnic distribution and prevalence of HIV infection. Of the drug users in this study, the majority (501) were non-injectors, suggesting a prevalence of $19.3 \%$ (201) of injection drug use. HIV infection was significantly higher among injection drug users compared with non-injection drug users $\left(\chi^{2}=3.39\right.$, $p=0.007)$. Age, sex, level of education and sexual debut were not significant predictors of HIV infection in this population (Table 2).

Any of the three infections was detected in 18.3\% (123/673) of drug users. Factors negatively associated with any infection (Table 3) included younger age (30 years old; adjusted odds ratio $[\mathrm{aOR}]=0.50,95 \% \mathrm{CI}: 0.33-0.76 ; p<0.001)$ and early sexual debut $(\mathrm{aOR}=0.54,95 \% \mathrm{CI}: 0.40-0.82 ; p<0.05)$. Younger age was also negatively associated with HIV infection ( $\mathrm{aOR}=0.53,95 \% \mathrm{CI}: 0.31-0.89 ; p<0.01)$ and $\mathrm{HCV}$ infection ( $\mathrm{aOR}=0.29,95 \% \mathrm{CI}: 0.15-0.56 ; p<0.001)$. IDU was positively associated with $\mathrm{HCV}(\mathrm{aOR}=5.37,95 \% \mathrm{CI}$ : 2.61-11.06; $p<0.001$ ), while early sexual debut had negative association with HCV infection (Fisher's Exact OR $=0.21$, 


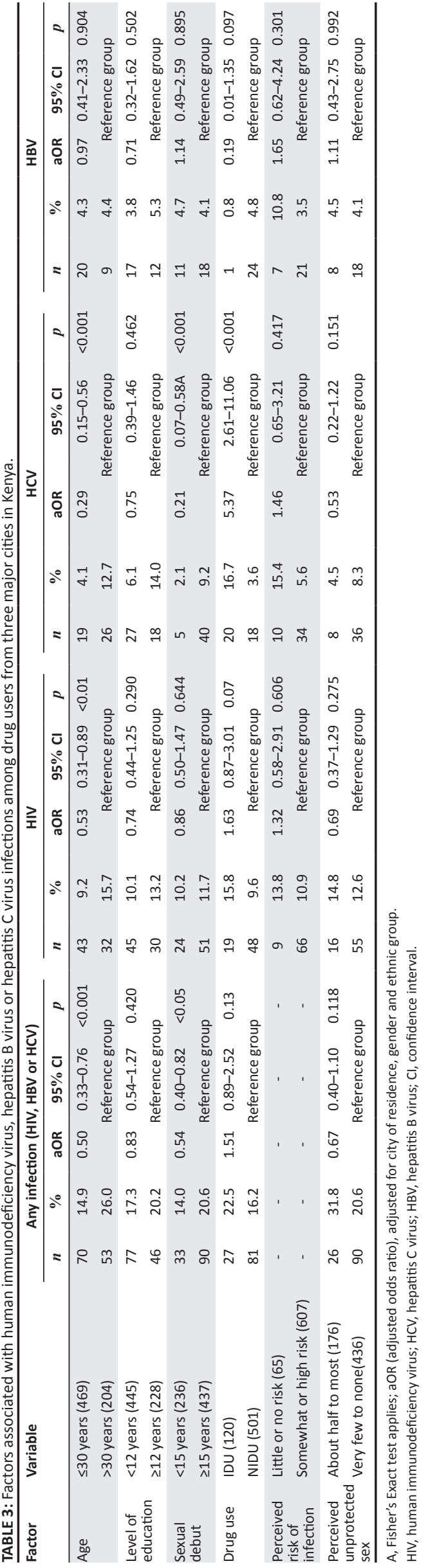

TABLE 4: Distribution of hepatitis B virus subgenotypes among drug users from three major cities in Kenya.

\begin{tabular}{llllccl}
\hline $\begin{array}{l}\text { Participant } \\
\text { ID. No }\end{array}$ & Gender & $\begin{array}{c}\text { Age } \\
\text { (years) }\end{array}$ & $\begin{array}{l}\text { Area } \\
\text { (town) }\end{array}$ & $\begin{array}{c}\text { Nested BCP } \\
\text { PCR }\end{array}$ & $\begin{array}{c}\text { Large S } \\
\text { PCR }\end{array}$ & Subgenotype \\
\hline 108 & Male & 20 & Nairobi & + & - & A1 \\
111 & Male & 30 & Nairobi & + & + & A1 \\
155 & Male & 21 & Nairobi & + & + & A1 \\
163 & Male & 23 & Nairobi & + & + & D6 \\
166 & Male & 22 & Nairobi & + & + & Mixed \\
174 & Male & 26 & Nairobi & + & + & D6 \\
244 & Male & 25 & Nairobi & + & + & A1 \\
282 & Male & 42 & Kisumu & + & - & A1 \\
332 & Male & 20 & Kisumu & + & + & A1 \\
426 & Female & 38 & Mombasa & - & + & D6 \\
445 & Male & 26 & Mombasa & + & + & A1 \\
496 & Male & 42 & Mombasa & + & + & Mixed \\
501 & Male & 38 & Mombasa & + & + & A1 \\
522 & Male & 23 & Mombasa & - & + & A1 \\
645 & Male & 28 & Mombasa & + & + A1 \\
729 & Male & 30 & Mombasa & + & + & Mixed \\
\hline
\end{tabular}

$\mathrm{BCP}$, basic core promoter; $\mathrm{PCR}$, polymerase chain reaction.

95\% CI: $0.07-0.58 ; p<0.001)$. None of these factors were associated with HBV infection (Table 3).

\section{Hepatitis B virus genotyping results}

Based on HBV serological test, 30 samples were positive for HBsAg and when subjected to genetic analysis to determine genotypes and subgenotypes, only 16 samples (53\%) out of the 30 samples were assigned or classified into genotypes based on two regions (BCP and S) that were amplified to obtain genotypes and subgenotype results. Table 4 shows the distribution of HBV subgenotypes from three recruitment sites (Kisumu, Nairobi, Mombasa) in Kenya.

Out of the 16 samples, 11 samples $(69 \%)$ constituted the majority and were assigned subgenotype A1. Three samples (19\%) were classified subgenotype D6 and two samples (13\%) failed subgenotype classification (mixed population). Among the two samples that failed subgenotype classification, one came from Kisumu and another from Nairobi. Out of the 11 subgenotypes A1 isolates identified, four were from Nairobi, five from Mombasa and two from Kisumu. Among those with D6 subgenotypes, two came from Nairobi and one from Mombasa. Figure 1 shows the distribution of $\mathrm{HBV}$ subgenotypes. There was no significant difference between the distribution of the subgenotypes in the different towns.

\section{Hepatitis $\mathrm{C}$ virus genotyping results}

Hepatitis $C$ virus molecular amplification was performed on 39 samples based on 5'UTR and NS5B regions for genotyping and subgenotyping classification. All the 39 samples were amplified and sequenced (21 samples on 5'UTR region and 18 samples on NS5B) to assign genotypes and subgenotypes. Five out of $21(24 \%)$ sequences were classified into genotype 1 , 14 out of $21(67 \%)$ into genotype 4 and one sample into genotype 2 (5\%). Among the 18 that were subgenotyped on NS5B region, 4 out of 18 samples (22\%) were classified into subgenotype $4 a, 13$ samples (72\%) into subgenotype 1a and two samples $(6 \%)$ were not subgenotyped. 


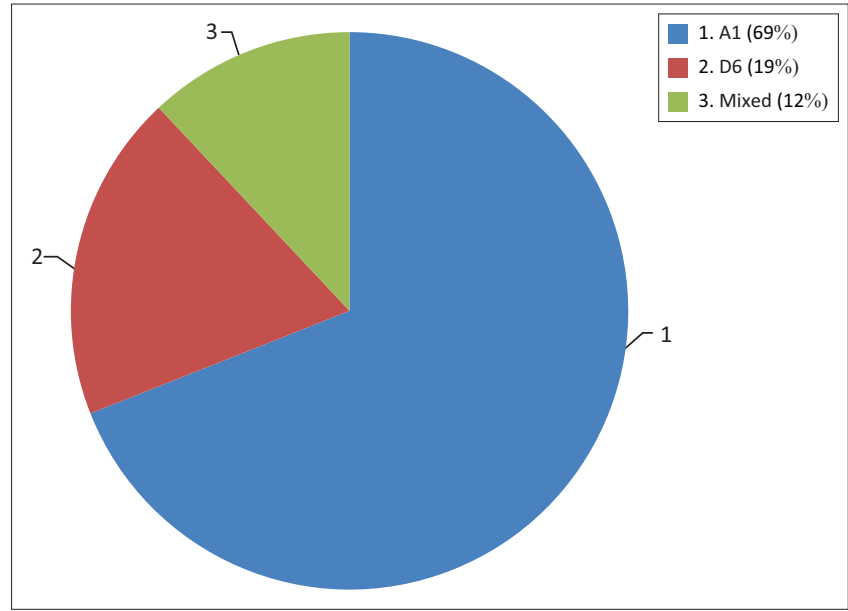

FIGURE 1: Hepatitis B virus subgenotypes isolated from Kenyan drug users.

\section{Discussion}

The majority of participants (93\%) in this study were male and a similar occurrence was observed among drugs users in Nairobi where male participants were in the majority compared to female participants. ${ }^{7}$ Infection with blood-borne viruses (HBV, HCV and HIV) presents a great public health challenge regarding the management, resource allocation and risks for co-infections owing to shared modes of transmission. This study found a higher prevalence of HIV $(11.1 \%)$ compared to $6 \%$ in the general population ${ }^{54}$ and $4.5 \% \mathrm{HCV}$ prevalence against $1.8 \%$ recorded among blood donor populations. ${ }^{14}$ However, a lower HBV prevalence of $6.5 \%$ was observed among drug users in this study compared to $13.3 \%$ reported among Nairobi urban slum dwellers. ${ }^{14}$ In a similar study conducted in Kisumu to determine the HBV and HCV among discordant couples irrespective of their HIV status, a prevalence of $4 \%$ and $5.6 \%$ for HCV and HBV infections, respectively, was reported.$^{55}$ The predominance of male participants (93\%) in this study was observed compared to female participants. The higher proportion of NIDUs (74\%) over IDUs (26\%) may account for the overall differences in the HBV prevalence among drug users. When compared, HBV prevalence was higher in Nairobi (52\%), followed by Mombasa (30\%) and Kisumu (17\%). We do not know at present why this difference is so dramatic and further research should be considered to try and understand the difference. The HBV vaccination in Kenya under the Expanded Programme on Immunisation was launched in Kenya in 2003 and participants would not have benefited from it nor would it have resulted in HBV prevalence. A catch-up/targeted vaccination for at-risk population was not available. However, more $\mathrm{HCV}$ infections (93\%) were concentrated in Mombasa and only 7\% in Nairobi. None was reported from Kisumu. We do not know exactly why the difference in HCV prevalence was so dramatic.

The IDU population, although small, shows a higher proportion of HCV mono-infections (93\%) and HCV/HIV coinfection (72\%). This finding is consistent with previous studies in Kenya ${ }^{29,46}$ and elsewhere. ${ }^{56,57}$ The use of unsafe injection practices has been linked with HCV and HIV infections among drug users. ${ }^{58}$ In contrast, $\mathrm{HBV} / \mathrm{HIV}$ co-infections were more common among NIDUs (83\%) compared with IDUs (17\%). This occurrence may be associated with unprotected sexual practices shown in previous studies..$^{59}$ The two samples with triple co-infections (HBV/HCV/HIV) and those with either $\mathrm{HBV} / \mathrm{HIV}$ or $\mathrm{HCV} / \mathrm{HIV}$ confirm the shared routes of transmission of the viruses as previously documented (1-3).

\section{Hepatitis B virus genotypes and phylogenetic analysis}

HBV DNA was detected in 50\% of the HBsAg-positive samples $(16 / 30)$. This percentage was much lower when compared to $60 \%$ reported from a previous study conducted among patients with and without liver disease in Sudan. ${ }^{60}$ The differences would have been owing to differences in population characteristics. Low detection of subgenotype A1 has been observed previously and thought to be associated with low viral loads. In this study, HBV genotype A $(11 / 16 ; 69 \%)$ was the most prevalent, followed by D (3/16; 19\%). Two samples failed subgenotype assignment and this was thought to be because of mixed infections. All A genotypes isolated belonged to subgenotype A1 while genotype $\mathrm{D}$ isolates belonged to subgenotype D6. The dominance of HBV subgenotype A1 is consistent with other previous studies among blood donors, ${ }^{61,62} \mathrm{HIV} / \mathrm{HBV}$ coinfected drug users, ${ }^{63}$ jaundiced outpatients ${ }^{36}$ and patients with liver disease $(\mathrm{HCC})^{36}$ in Kenya and India. ${ }^{64} \mathrm{HBV}$ subgenotype A1 is believed to be endemic in Africa ${ }^{36}$ and mainly found in the eastern, central and southern Africa. ${ }^{65}$ Isolation of only $\mathrm{HBV}$ subgenotype A1 from all the three recruitment sites (Mombasa, Nairobi and Kisumu) is consistent with its endemicity and predominance in Eastern Africa as previously reported. ${ }^{60,62,64}$ Although HBV subgenotype A2 has been reported among blood donors, ${ }^{66}$ it was found to be a mis-classification ${ }^{36}$, which is consistent with our study that found none despite samples obtained across three major towns in Kenya, suggesting a need for continuous molecular studies to confirm HBV genetic diversity in Kenya. HBV genotype D was detected and its subgenotype grouped into D6. This finding was consistent with an earlier study among blood donors. ${ }^{36}$ However, our study shows a higher percentage (19\%) of HBV subgenotype D6 compared to $4 \%$ found in a previous study. ${ }^{7}$ This subgenotype (D6) has also been reported in Egypt, ${ }^{67}$ North Africa ${ }^{54}$ and Sudan (Khartoum). ${ }^{15}$

\section{Hepatitis $\mathbf{C}$ virus genotypes and subgenotypes}

Phylogenetic analysis of HCV isolates revealed the presence of HCV genotypes (1,2 and 4) and two subgenotypes (1a and $4 \mathrm{a})$. These results are consistent with previous studies that were conducted among blood donors ${ }^{55}$ and drugs users ${ }^{56}$ in Kenya. In this study, HCV subgenotype 1a was predominant (72\%). The predominance of HCV subgenotype 1a also has been reported in West Africa ${ }^{57}$ and almost exclusively in North America ${ }^{58}$ However, certain factors favour predominance of specific HCV genotypes and subgenotypes in different geographical locations within a country around the world. For 
instance, in a previous study, HCV genotype 2a was found to be predominant among the blood donor population in Kenya, ${ }^{55}$ whereas in this study, HCV subgenotype $1 \mathrm{a}$ is predominant among the population of drug users, especially the IDUs, suggesting a need for continuous monitoring of these for better treatment outcomes that entirely depend on $\mathrm{HCV}$ genotyping results. Similar observations were reported from a study conducted in Pakistan to determine the distribution of $\mathrm{HCV}$ genotypes in different geographic locations. ${ }^{59}$ Although our study generated tangible information on HBV and HCV molecular epidemiology among drug users, including the management of these viral infections, there were some limitations. Majority of the participants were male (93\%); females may have been underrepresented or be less likely to use drugs compared to males in Kenya. Both injecting and NIDUs' participation were not balanced and evenly distributed in each town represented in the analysis; hence, a bias in data analysis may have occurred.

\section{Conclusion}

In conclusion, our study found HBV, HCV and HIV prevalence of $4.3 \%, 6.5 \% 11.9 \%$, respectively, which were detected including their co-infections (HBV/HIV, $\mathrm{HCV} / \mathrm{HIV}, \mathrm{HBV} / \mathrm{HCV} / \mathrm{HIV})$. Molecular analysis revealed HBV genotypes A1, D6 and mixed genotypes in circulation, and HCV subgenotypes $1 \mathrm{a}$ and $4 \mathrm{a}$ were isolated among drug users. This high level of genetic diversity exhibited by HBV and $\mathrm{HCV}$ isolates requires continuous monitoring for effective management of the patients and full implementation of harm reduction strategies to reduce mortality and morbidity associated with these viral infections.

\section{Acknowledgements}

The study was funded by the International AIDS Society (IAS) and the National Institute on Drug Abuse (NIDA), main sponsor; the International Society for Infectious Diseases (ISID); the University of the Witwatersrand Africa Residency Grant Programme; and the National Research Foundation of South Africa.

The authors are grateful to the study participants (drug users who provided their samples) and funders and/or sponsors of the study. They also thank the International AIDS Society (IAS) and the National Institute on Drug Abuse (NIDA), main sponsor; the International Society for Infectious Diseases (ISID) and the Wits Africa Residency Grant Programme.

\section{Competing interests}

The authors declare that they have no financial or personal relationships which may have inappropriately influenced them in writing this article.

\section{Authors' contributions}

M.O. and J.W. conceived and designed the overall study design while A.K., C.Y.C. and M.O. conceived and designed the molecular analyses. C.Y.C. and M.O. performed the molecular analyses while R.O.O. analysed the data. All authors were involved in the writing of this article.

\section{References}

1. Soriano V, Vispo E, Labarga P, Medrano J, Barreiro P. Viral hepatitis and HIV coinfection. Antiviral Res. 2005;85:303-315. https://doi.org/10.1016/j.antiviral. 2009.10.021

2 Meireles LC, RuiTM, Pierre VD. Three decades of hepatitis B control with vaccination World JHepatol.2015;7(18):2127. https://doi.org/10.4254/wjh.v7.i18.2127

3. Franco E, Bagnato B, Marino MG, Meleleo C, Serino L, Zaratti L. Hepatitis B: Epidemiology and prevention in developing countries. World J Hepatol.2012;4(3): 74-80. https://doi.org/10.4254/wjh.v4.i3.74

4. Mohamed AA, Elbedewy TA, El-Serafy M, El-Toukhy N, Ahmed W, El Din ZA. Hepatitis C virus: A global view. World JHepatol.2015;7(26):2676. https://doi. org/10.4254/wjh.v7.i26.2676

5. How AIDS Changed Everything MDG6:15 years, 15 lessons of hope from the AIDS responses. In. Geneva, Switzerland: UNAIDS; 2015.

6. UNDOC. World Drug Report 2011 [homepage on the Internet]. Available from: http://www.unodc.org/documents/data-and-analysis/WDR2011/World_Drug Report_2011_ebook.pdf

7. Tun W, Sheehy M, Broz D, et al. HIV and STI prevalence and injection behaviors among people who inject drugs in Nairobi: Results from a 2011 bio-behavioral study using respondent-driven sampling. AIDS Behav.2015;19(1):24-35. https:// doi.org/10.1007/s10461-014-0936-3

8. Beckerleg S, Telfer M, Hundt GL. The rise of injecting drug use in East Africa: A case study from Kenya. Harm Reduct J. 2005;2:12. https://doi.org/10.1186/14777517-2-12

9. Kharsany ABM, Karim QA. HIV Infection and AIDS in Sub-Saharan Africa: Current status, challenges and opportunities. Open AIDS J. 2016;10:34-48. https://doi. org/10.2174/1874613601610010034

10. Uganda AIDS Commission (UAC). HIV and AIDS Uganda Country Progress Report 2013. Kampala: UAC; 2014. [cited 2016 Feb 14]. Available from http://www. unaids.org/sites/default/files/country/documents/UGA_narrative_report 2015.pdf

11. Joint United Nations Programme on HIV/AIDS. Prevention gap report. Geneva: Joint United Nations Programme on HIV/AIDS; 2016. [cited 2017 March 02] Available from: http://www.unaids.org/sites/default/files/media_asset/2016prevention-gap-report en.pdf

12. Stabinski PO, Oliver L, David S, et al. Reynolds virus and sexual behavior in Rakai, Uganda. J Med Virol.2011;83(5):796-800. https://doi.org/10.1002/jmv.22051

13. Matee MIN, Magesa PM, Lyamuya EF. Seroprevalence of human immunodeficiency virus, hepatitis $B$ and $C$ viruses and syphilis infections among blood donors at the Muhimbili National Hospital in Dar es Salaam, Tanzania. BMC Public Health. 2006;6:21. https://doi.org/10.1186/1471-2458-6-21

14. Kerubo $G$, Khamadi S, Okoth V, et al. Hepatitis B, Hepatitis C and HIV-1 Coinfection in two informal urban settlements in Nairobi, Kenya. PLoS One. 2015;10(6): e0129247. https://doi.org/10.1371/journal.pone.0129247

15. Mwangi J. Viral markers in blood donor population. East Afr Med J.1999;76: 135-137.

16. O'Reilly JI, Ocama P, Opio CK, Alfred A, Paintsil E, Seremba E, Sofair AN. Risk Factors and Seroprevalence of Hepatitis $\mathrm{C}$ among Patients Hospitalized at Mulago Hospital, Uganda. J Trop Med. 2011;2011:598341

17. B.H. Tess, A. Levin, G. Brubaker, J. Shao, J.E. Drummond, H.J. Alter, et al. Seroprevalence of hepatitis $C$ virus in the general population of northwest Tanzania Am J Trop Med Hyg, 62 (2000), pp. 138-141. https://doi.org/10.4269/ ajtmh.2000.62.138

18. Cheng HH. Epidemiologic studies on HCV and HBV infections among intravenous drug users in the area with high HIV infection. Chin J Epidemiol. 1993;14: 275-278.

19. SantanaROE, Malé GML, Hernandez SJF, Liminana CJM, Martin SAM. Prevalence of serologic markers of HBV-HDV-HCV and HIV in non-injection drug users compared to injection drug users in Gran Canaria, Spain. Eur J Epidemiol. 1998;14:555-561. https://doi.org/10.1023/A:1007410707801

20. Telles PR, Bastos FI, Guydish J, et al. Risk behavior and HIV seroprevalence among injecting drug users in Rio de Janeiro, Brazil. AIDS.1997;11:S35-S42.

21. Thio CL, Seaberg EC, Skolasky R Jr, et al. HIV-1, hepatitis B virus, and risk of liverrelated mortality in the Multicenter Cohort Study (MACS). Lancet. 2002;360: 1921-1926. https://doi.org/10.1016/S0140-6736(02)11913-1

22. Kenya Ministry of Health, National AIDS Control Council, National AIDS and STI Control Programme. Kenya AIDS response progress report 2014: Progress towards zero. http://www.unaids.org/sites/default/files/country/documents/ KEN_narrative_report_2014.pdf (2014). Accessed 14 Nov 2014

23. Syvertsen JL, Agot K, Ohaga S, Strathdee SA, Camlin CS, Omanga E, et al. Evidence of injection drug use in Kisumu, Kenya: Implications for HIV prevention. Drug and alcohol dependence. 2015;151:262-6. pmid:25861945. https://doi.org/10.1016/ j.drugalcdep.2015.02.037

24. Tan AX, Kapiga S, Khoshnood K, Bruce RD. Epidemiology of drug use and HIVrelated risk behaviors among people Who inject drugs in mwanza. Tanzania PLos One. 2015;10:e0145578. https://doi.org/10.1371/journal.pone.0145578 
25. Lambdin BH, Bruce RD, Chang O, et al. Identifying programmatic gaps: inequities in harm reduction service utilization among male and female drug users in Dar es Salaam, Tanzania. PLoS One. 2013;8(6):e67062. https://doi.org/10.1371/journal. palaam, Tanzan 0067062

26. Dahoma MJU, Salim AA, Abdool R, et al. HIV and substance abuse: The dual epidemics challenging Zanzibar. Afr J Drugs Alcohol Stud. 2006;5(2):130-139.

27. Johnston L, Saumtally A, Corceal S, Mahadoo I, Oodally F. High HIV and hepatitis C prevalence amongst injecting drug users in Mauritius: Findings from a population size estimation and respondent driven sampling survey. Int J Drug Policy. 2011;22(4):252-258. https://doi.org/10.1016/j.drugpo.2011.05.007

28. Hyams KC, Okoth FA, Tukei PM, Mugambi M, Johnson B, Morrill JC, Gray GC, Woody JN. Epidemiology of hepatitis B in Eastern Kenya. J Med Virol. 1989; 28:106-109.

29. Mwatelah RS, Lwembe RM, Osman S, et al. Co-Infection burden of hepatitis C virus and human immunodeficiency virus among injecting heroin users at the Kenyan Coast. PLoS One.2015;10(7):e0132287. https://doi.org/10.1371/journal. pone.0132287

30. Seeger C, Mason WS. Hepatitis B virus biology. MicrobiolMolBiol Rev. 2000;64: 51-68. https://doi.org/10.1128/MMBR.64.1.51-68.2000

31. Bouckaert R, Alvarado-Mora MV, Pinho JR. Evolutionary rates and HBV: Issues of rate estimation with Bayesian molecular methods. AntivirTher. 2013;18:497-503. rate estimation with Bayesian molecu
https://doi.org/10.3851/IMP2656

32. Nowak MA, Bonhoeffer $S$, Hill AM, et al. Viral dynamics in hepatitis $B$ virus infection. ProcNat|AcadSci U S A.1996;A93:4398-4402. https://doi.org/10.1073/ pnas.93.9.4398

33. Tatematsu K, Tanaka $Y$, Kurbanov F, et al. A genetic variant of hepatitis $B$ virus divergent from known human and ape genotypes isolated from a Japanese patient and provisionally assigned to new genotype J. J Virol. 2009;83:1053810547. https://doi.org/10.1128/JVI.00462-09

34. Yousif $M$, Kramvis A. Genotype $D$ of hepatitis $B$ virus and its subgenotypes: An update. Hepatol Res. 2013;43:355-364. https://doi.org/10.1111/j.1872-034X. 2012.01090.x

35. Schaefer S. Hepatitis B virus taxonomy and hepatitis B virus genotypes. World Gastroenterol.2007;13:14-21. https://doi.org/10.3748/wjg.v13.i1.14

36. Ochwoto M, Chauhan R, Gopalakrishnan D, et al. Genotyping and molecular characterization of hepatitis B virus in liver disease patients in Kenya. Infect Genet Evol. 2013;20:103-110. https://doi.org/10.1016/j.meegid.2013.08.013

37. Ochwoto M, Kimotho J, Oyugi J, et al. Hepatitis B virus genotypes and unique recombinants circulating among outpatients in selected hospitals in Kenya. Int Infect Dis.2016;45:451-452. https://doi.org/10.1016/j.ijid.2016.02.957

38. Ochwoto $\mathrm{M}$, Kimotho $\mathrm{JH}$, Oyugi J, et al. Hepatitis $\mathrm{B}$ infection is highly prevalent among patients presenting with jaundice in Kenya. BMC Infectious Diseases. 2016;16:101. doi:10.1186/s12879-016-1409-2. https://doi.org/10.1186/s128792016;16:101.

39. Timm J, Roggendorf M. Sequence diversity of hepatitis C virus: Implications for immune control and therapy. World J Gastroenterol.2007;13:4808-4817. https:// doi.org/10.3748/wjg.v13.i36.4808

40. Smith DB, Bukh J, Kuiken C, et al. Expanded classification of hepatitis C virus into 7 genotypes and 67 subtypes: Updated criteria and genotype assignment Web resource. Hepatology.2014;59:318-327. https://doi.org/10.1002/hep.26744

41. Smith DB, Pathirana S, Davidson F, et al. The origin of hepatitis $C$ virus genotypes. J Gen Virol.1997;78((Pt 2)):321-328.

42. Pybus OG, Cochrane A, Holmes EC, Simmonds $P$. The hepatitis $C$ virus epidemic among injecting drug users. Infect Genet Evol.2005;5:131-139. https://doi. org/10.1016/j.meegid.2004.08.001

43. Magiorkinis G, Magiorkinis E, Paraskevis D, et al. The global spread of hepatitis $C$ virus $1 \mathrm{a}$ and $1 \mathrm{~b}$ : Aphylodynamic and phylogeographic analysis. PLoS Med. 2009;6:e1000198. https://doi.org/10.1371/journal.pmed.1000198

44. Messina, J.P., Humphreys, I., Flaxman, A., Brown, A., Cooke, G.S., Pybus, O.G. et al Global distribution and prevalence of hepatitis $C$ virus genotypes. Hepatology. 2015; 61: 77-87. https://doi.org/10.1002/hep.27259

45. Webale, M.K., Budambula, V., Lihana, R. Musumba, F.O., Nyamache, A.K., Budambula, N.L., et al. Hepatitis B virus sero-profiles and genotypes in HIV-1 infected and uninfected injection and non-injection drug users from coastal Kenya. BMC Infect Dis. 2015;15:299.

46. Muasya T, Lore W, Yano $K$, et al. Prevalence of hepatitis $C$ virus and its genotypes among a cohort of drug users in Kenya. East AfrMed J.2008;85(7):318-325. https://doi.org/10.1186/s12879-015-1060-3

47. Strezoska Ž, Licon A, Haimes J, et al. Optimized PCR conditions and increased shRNA fold representation improve reproducibility of pooled shRNA screens. PLOS One. 2012;7(8):e42341. https://doi.org/10.1371/journal.pone.0042341
48. Singh OP, Bali P, Hemingway J, Subbarao SK, Dash AP, Adak T. PCR-based methods for the detection of L1014 kdr mutation in Anopheles culicifaciessensulato. Malaria J.2009;8(1):1. https://doi.org/10.1186/1475-2875-8-154

49. Lindh M, Anderson AS, Gusdal A. Genotypes, nt 1858 variants and geographic origin of hepatitis B virus- Large scale analysis using a new genotyping method. $J$ infect Dis. 1997;175:1285-1293. https://doi.org/10.1086/516458

50. Weinberger KM, Wiedenmann E, Bohm S, Jilg W. Sensitive and accurate quantitation of hepatitis B virus DNA using a kinetic fluorescence detection system (TaqMan PCR).J Virol Meth. 2000;85:75-82. https://doi.org/10.1016/ S0166-0934(99)00154-8

51. Chen CY, Crowther C, Kew MC, Kramvis A. Avaline to phenylalanine mutation in the precore region of hepatitis $B$ virus causes intracellular retention and impaired secretion of HBe-antigen. Hepatol Res. 2008;38:580-592. https://doi.org/ 10.1111/j.1872-034X.2007.00315.X

52. Chan S, McOmish F, Holmes E, et al. Analysis of a new hepatitis $C$ virus type and its phylogenetic relationship to existing variants. J Gen Virol.1992;73:1131-1141. https://doi.org/10.1099/0022-1317-73-5-1131

53. Chen Z, Weck KE. Hepatitis C virus genotyping: Interrogation of the 5 'untranslated region cannot accurately distinguish genotypes $1 \mathrm{a}$ and $1 \mathrm{~b}$. J ClinMicrobiol. 2002;40(9):3127-3134. https://doi.org/10.1128/JCM.40.9.3127-3134.2002

54. National AIDS and STI Control Programme (NASCOP) National AIDS and STI Control Programme, Annual Report. Nairobi, Kenya: NASCOP; 2012.

55. Njenge KH, Bukusi EA, KutimaHL. The prevalence of hepatitis $B$ and $C$ viruses among HIV serodiscordant couples in Kisumu Kenya. Afr J Health Sci.2016;29(1): among

56. C Folch, J Casabona, A Espelt, et al. High prevalence and incidence of HIV and HCV among new injecting drug users with a large proportion of migrants-is prevention failing? Subst Use Misuse, 51 (2016), pp. 250-260.https://doi.org/10.3109/10826 084.2015.1092991

57. Vickerman P, Martin NK, Roy A, Beattie T, Jarlais DD, Strathdee S, Wiessing L, Hickman $\mathrm{M}$. Is the HCV-HIV co-infection prevalence amongst injecting drug users a marker for the level of sexual and injection related HIV transmission? Drug Alcohol Depend. 2013;132:172-181. https://doi.org/10.1016/j.drugalcdep.2013. 01.020

58. Muñoz F, Burgos JL, Cuevas-Mota J, Teshale E, Garfein RS. Individual and socioenvironmental factors associated with unsafe injection practices among young
adult injection drug users in San Diego. AIDS Behav. 2015;19(1):199-210. pmid:24920342. https://doi.org/10.1007/s10461-014-0815-y

59. Rich, JD; Anderson, BJ; Schwartzapfel, B; Stein, MD. Sexual risk for hepatitis B virus among hepatitis $C$ virus-negative heroin and cocaine users. Epidemiol. Infect 2006, 143, 478-484. https://doi.org/10.1017/S0950268805005248

60. Yousif M, Mudawi H, Bakhiet S, Glebe D, Kramvis A. Molecular characterization of hepatitis $B$ virus in liver disease patients and asymptomatic carriers of the virus in Sudan. BMC Infect Dis. 2013;13:328. https://doi.org/10.1186/14712334-13-328

61. Usuda S, Okamoto $H$, Iwanari $H$, et al. Serological detection of hepatitis B virus genotypes by ELISA withmonoclonal antibodies to type-specific epitopes in the preS2-region product. JVirol Meth.1999;80:97-112. https://doi.org/10.1016/ S0166-0934(99)00039-7

62. Mwangi J, Nganga Z, Songok E, et al. Molecular genetic diversity of hepatitis B virus in Kenya. Intervirology.2008;51:417-421. https://doi.org/10.1159/000205526

63. Kibaya RM, Lihana RW, M Kiptoo, et al. Characterization of HBV among HBV/HIV-1 Co-Infected injecting drug users from Mombasa, Kenya. Curr HIV Res.2015;13(4): 292-299. https://doi.org/10.2174/1570162X13666150121113217

64. Gopalakhrishnan D, Keyter M, Shenoy KT, Leena KB, Thayumanavan L, et al. (2013) Hepatitis B virus subgenotype A1 predominates in liver disease patients from Kerala, India. World J Gastroenterol 19: 9294-9306. https://doi.org/10.3748/wjg. Kerala, India.
v19.i48.9294

65. Kramvis A, Kew MC. Epidemiology of hepatitis B virus in Africa, its genotypes and clinical associations of genotypes. Hepatol Res. 2007;37(Suppl):S9-S19. https:// doi.org/10.1111/j.1872-034X.2007.00098.x

66. Mwangi J, Nganga Z, Songok E, Kinyua J, Lagat N, Muriuki J, Lihana R, Khamadi S, Osman S, Lwembe R, et al: Molecular genetic diversity of hepatitis B virus in Kenya. Intervirology. 2008, 51 (6): 417-421. 10.1159/000205526. https://doi.org/ $10.1159 / 000205526$

67. Saudy N, Sugauchi F, Tanaka Y, et al. Genotypes and phylogenetic characterization of hepatitis B and delta viruses in Egypt. J Med Virol. 2003;70(4):529-536. https:// doi.org/10.1002/jmv.10427

68. Mahgoub S, Candotti D, El-Ekiaby M, Allain JP. Hepatitis B virus (HBV) infection and recombination between HBV genotypes $D$ and $E$ in asymptomatic blood donors from Khartoum Sudan. J ClinMicrobiol. 2011;49(1):298-306. https://doi.org/ 10.1128/JCM.00867-10 